\title{
Willingness to Pay for Critical Land
}

\author{
$1^{\text {st }}$ Sulistya Rini Pratiwi \\ Universitas Tarakan Borneo \\ Indonesia \\ miss.rainy@ymail.com
}

\author{
$2^{\text {nd }}$ Erry Purnomo \\ Universitas Tarakan Borneo
}

\author{
$3^{\text {rd }}$ Said Usman \\ Universitas Tarakan Borneo
}

\begin{abstract}
This study was conducted in order to find the effect of community socioeconomic conditions on farmers' Willingness To Pay (WTP) and farmers' willingness to move to lands that were not critical or to better land areas (Willingness To Leave / WTL). The research method used to calculate the farmers' willingness to pay the land restoration is the WTP Method, and Ordinal logistic regression analysis is used to determine the influencing factors to the opportunities of the critical land recovery activities. From the results of the study, the efforts to recover critical or degraded land are still low. Farmers of the study respondents has only carried out the fertilization process, and they even used the land over the land productivity. The factors that have a significant effect to the possibility of WTP for the land recovery is the long stay variable. Whereas the significant effect to the WTL model is the income variable.
\end{abstract}

Keywords: willingness to pay, critical land

\section{INTRODUCTION}

Sustainable development according to Law No. 4 of 1982 concerning Basic Environmental Provisions that were perfected by the Law No. 23 of 1997 concerning Environmental Management, can be achieved with a condition that environmental management must be based on harmonious and balanced environmental capabilities. USA's per capita income was US \$ 10,391 [1], compared to Indonesia which is only US $\$ 3,716$ so that Indonesia is considered unable improving appropriate environmental quality. The natural resource usage must be planned by considering the ecological conditions without ignoring the economic values so improve environmental quality is possible.

One of the natural resource usage is the use of agricultural land. Land is a very important resource to meet all needs of life, so its management is supposed to be appropriate with its ability so the land productivity will not be reduced [2]. In the land use it often was not paying attention to the preservation of the land, especially on the land that has limitations both physical and chemical limitations [3]. Consider this condition, if it occur continuously, it is worrying that the land will become critical land which will lead to the decreased soil fertility and productivity.

Critical land is a critical condition of land that occurs due to the imbalance of the land use to the land capability, resulting the physically, chemically and biologically land damage. To prevent the occurrence of the critical land condition, a land rehabilitation is needed. A land rehabilitation is a serious effort to restore the land conditions throughout physically, chemically and organically so that the land can be productive again [4]. In general, the critical land is a decrease in environmental quality as a result of unwisely various land resource uses and the of the use that is not following the existing regulations. Thus, the effort to rehabilitation and prevention the critical land have to be conducted immediately.

Important reasons for environmental assessments are related to macroeconomic policies, and for decisions related to the allocation of production factors it is for the efficiency at the micro level [5]. The monetary benefit and impact assessment must be based on an appropriate assessment of the physical benefits and impacts and their linkages, because the impacts will result the changes of environmental productivity and quality. This assessment can be done by various methods and approaches $[6,7]$.

Land degradation is an insidious, gradual process of farmers may not easily perceive its severity. The smallholder farmers' decision-making procedures are strongly based on their perceptions of the forces that drive degradation [8] and its consequences on their lives and livelihoods. Perception will partly control awareness, goals and practical actions. Local perception refers to the causes and status of land degradation as farmers detect and express it as occurring on their lands [9]. Both perception and knowledge guides decision making and consequently, farmers' action on land conservation and adoption of sustainable land management practices [10, 11]. Interpretations of environmental change are culturally constructed and need to be thoroughly examined for a sound understanding of farmer behavior. Nevertheless, the results of research in the West Harerghe Zone of Oromia National Regional State, Ethiopia, it was more than $55 \%$ of farmers stated that they felt a significant decrease in the land productivity due to the critical land [12]. This shows that the impact of degraded land cannot be underestimated.

Weaknesses in the CVM method are biases if the WTP value generated in the CVM study is lower or higher than the actual value $[13,14,15,16]$. But in fact, some studies still use this 


\begin{tabular}{|l|l|l|}
\hline Characteristics & \multicolumn{1}{|c|}{ Majority } & \multicolumn{1}{|c|}{ Percentage } \\
\hline \multirow{5}{*}{} & $\begin{array}{l}\text { IDR 2.000.000- } \\
\text { IDR 3.000.000 }\end{array}$ & $18 \%$ \\
\cline { 2 - 3 } & $\begin{array}{l}\text { IDR 3.000.000 or } \\
\text { more }\end{array}$ & $64 \%$ \\
\hline \multirow{5}{*}{ WTP } & 0 & $2 \%$ \\
\cline { 2 - 3 } & <IDR 10.000 & $16 \%$ \\
\cline { 2 - 3 } & $\begin{array}{l}\text { IDR 11.000- IDR } \\
\text { 20.000 }\end{array}$ & $18 \%$ \\
\cline { 2 - 3 } & $\begin{array}{l}\text { IDR 21.000- IDR } \\
\text { 30.000 }\end{array}$ & $62 \%$ \\
\cline { 2 - 3 } & $>$ IDR 30.000 & $2 \%$ \\
\hline \multirow{3}{*}{ Plan to move } & Yes & $6 \%$ \\
\cline { 2 - 3 } & No & $94 \%$ \\
\hline \multirow{2}{*}{ Marital status } & Married & $86 \%$ \\
\cline { 2 - 3 } & Other & $14 \%$ \\
\hline \multirow{2}{*}{ Land ownership } & Own & $71 \%$ \\
\cline { 2 - 3 } & Rent & $29 \%$ \\
\hline \multirow{3}{*}{ Farming experience (years) } & $0-9$ & $49 \%$ \\
\cline { 2 - 3 } & $20-$-Oct & $43 \%$ \\
\cline { 2 - 3 } & $>21$ & $8 \%$ \\
\hline \multirow{3}{*}{ Landholding size (ha) } & $2-$ Jan & $67 \%$ \\
\cline { 2 - 3 } & $4-$ Mar & $27 \%$ \\
\cline { 2 - 3 } & $>5$ & $69 \%$ \\
\hline \multirow{3}{*}{ Family Size } & $2-4$ & $7 \%$ \\
\cline { 2 - 3 } & $5-7$ & $24 \%$ \\
\cline { 2 - 3 } & $>7$ & \\
\hline & & \\
\hline
\end{tabular}

method to measure the value of the impact of critical land. In the Czech Republic, areas in which has many industrial activities were vulnerable increasing the degraded and contaminated land. The survey results showed that a willingness to pay was increased according to the dependence on income, gender and also the location of the respondent's residence [17].

Based on these findings, this study was conducted in order to find the effect of community socioeconomic conditions on farmers' willingness to pay (WTP) and farmers' willingness to move to lands that were not critical or to better land areas (willingness to leave / WTL).

\section{METHOD}

The contingency valuation method is used to estimate the economic value of various ecosystems and environmental services. This method uses a willingness to pay or receive compensation approach. It is a technique in expressing preferences because it asks people to state their judgment and appreciation. It also shows how the respondents concern for environmental goods and services based on the great benefits for all parties so that preservation efforts are needed in order to not lose those benefits. The CVM approach is carried out by determining the willingness to pay (WTP) of consumers [18].

Economic value of goods or services is measured by the accumulation of the WTP individuals involved for the goods or services [19]. WTP reflects the individual preferences to pay for goods and services. Questions in WTP questioners are related to the availability of users to issue rewards for the goods or services received. The approach used in the WTP method is based on user preferences and perceptions of the tariff of the goods or services

\section{RESULT AND DISCUSSION}

\section{Socio-economic and demographic attributes of respondents}

The average farmland owned by the farmers is 2 ha. Based on the results of the survey (Table 1), most farmers choose to stay on the current agricultural land. This is because the farmers have not financial stable to frequently move. However, until now the farmers do not have specific methods to deal with the land degradation.

TABLE 1. DEMOGRAPHIC AND SOCIO-ECONOMIC ATTRIBUTES OF THE RESPONDENTS $(\mathrm{N}=51)$

\begin{tabular}{|l|l|l|}
\hline \multicolumn{1}{|c|}{ Characteristics } & \multicolumn{1}{|c|}{ Majority } & \multicolumn{1}{c|}{ Percentage } \\
\hline \multirow{2}{*}{ Sex } & Male & $71 \%$ \\
\cline { 2 - 3 } & Female & $29 \%$ \\
\hline \multirow{3}{*}{ Age } & $>30$ & $24 \%$ \\
\cline { 2 - 3 } & $31-40$ & $47 \%$ \\
\cline { 2 - 3 } & $>41$ & $29 \%$ \\
\hline \multirow{3}{*}{ Education } & Primary School & $25 \%$ \\
\cline { 2 - 3 } & Junior High School & $47 \%$ \\
\cline { 2 - 3 } & Senior High School & $28 \%$ \\
\hline Income & <IDR 2.000.000 & $18 \%$ \\
\hline
\end{tabular}

The average number of family members per household is 6 people. Almost each year these families have increased the number of family members. The majority of the main labor comes from farmers' family members. However, during the planting and harvest season farmers usually have extra labors paid daily.

$62 \%$ of the WTPs selected by farmers are between IDR 20,000 - IDR 30,000 with an average of IDR 21,196 [20]. Most farmers choose to contribute their energy rather than their money in efforts to recover the critical land. If the respondent is asked to pay, then the respondent can only afford the lowest value. In addition, the level of critical land understanding of the farmers' was still low. So the farmers were tend to ignore, not willing to participate, in critical land recovery activities [21, 22, 23].

\section{Determinant The Farmers' WTP}

Ordinal logistic regression analysis is used to determine the influencing factors to the opportunities of the critical land recovery activities. The activity was pointed by selecting the WTP scenario chosen by the farmers as the respondents. Beside the WTP opportunities, this study also analyzed the influencing factors of farmers' willingness to leave their land in order to find other better areas (Willingness To Leave / WTL). Table 2 shows the results of the regression of both models (WTP and WTL). 
TABLE 2. REGRESSION RESULTS FOR WTP AND WTL MODEL

\begin{tabular}{|l|c|c|c|c|c|c|}
\hline \multirow{2}{*}{ Variabel Independen } & \multicolumn{3}{|c|}{ WTP } & \multicolumn{3}{c|}{ WTL } \\
\cline { 2 - 7 } & Koefisien & $\mathbf{P}>|\mathbf{z}|$ & Odds Ratio (OR) & Koefisien & $\mathbf{P}>|\mathbf{z}|$ & Odds Ratio (OR) \\
\hline Income & 0.0590 & 0.856 & 1.06 & 1.425 & 0.047 & 4.15 \\
\hline Age & -0.0253 & 0.352 & 0.97 & 0.0648 & 0.482 & 1.06 \\
\hline Long Stay & 0.1311 & 0.035 & 0.71 & 0.1434 & 0.465 & 1.15 \\
\hline
\end{tabular}

a. Processed Data, 2019

In the WTP model regression results, the long stay variable has a significant effect. This means that the longer the farmer occupies the area, the higher the chance of the WTP scenario chosen by the farmer. In addition, the increasing farmers' incomes increases the chances of the critical land recovery activities [16]. Related to the land recovery activities, the easiest way is doing a periodic fertilization process on the land [24].

The results of the WTL regression model, the income variable shows the highest OR value (4.15). This value indicates that the farmers' income will be increased 4.15 times the effort to move to another better land. The income variable significantly influences the change in the farmer WTL variable. The high level of income will make farmers tend to choose another better land or area $[25,26]$.

\section{CONCLUSION}

Land degradation is one of the causes of decreasing agricultural land productivity. Some efforts that can be done are controlling the land use, watering or fertilizing. From the results of the study, the efforts to recover critical or degraded land are still low. Farmers of the study respondents has only carried out the fertilization process, and they even used the land over the land productivity. The factors that have a significant effect to the possibility of WTP for the land recovery is the long stay variable. Whereas the significant effect to the WTL model is the income variable.

Socialization measures are needed in order to direct the perception and participation of local communities so that they holistically understand the meaning of the land conservation through the rehabilitation of agricultural land. In the context of this socialization, it is also necessary to formulate a level of material depth that needs to be conveyed related to the context of events in the existing field (balance of theory and practice).

\section{ACKNOWLEDGMENT}

This research was financially supported by the Ministry of Research, Technology and Higher Education. And many thanks to Mr Nurgianto as the coordinator of farmer. The data support from team survey.

\section{REFERENCES}

[1] Saygin, S.D. 2017. Strategies to Enhance Sustainability of Land Resources in Arid Regions, Arid Environments and Sustainability, Hasan Arman and Ibrahim Yuksel, IntechOpen, DOI 10.5772/intechopen.72492. Available from: https://www.intechopen.com/books/arid-environments-andsustainability/strategies-to-enhance-sustainability-of-land-resources-inarid-regions.

[2] Ziadat, F., Bunning, S. and Pauw, E.D. 2017. Land resource planning for sustainable land management. Food And Agriculture Organization Of The United Nations Rome.

[3] Muljadi, D., dan M. Soepraptohardjo. 1975. Masalah Data Luas dan Penyebaran TanahTanah Kritis. Simposium Pencegahan dan Pemulihan Tanah Kritis dalam Rangka Pengembangan Wilayah. Jakarta.

[4] Arsyad, S. 1989. Konservasi Tanah dan Air. Departemen Ilmu Tanah dan Sumberdaya Lahan, IPB press.

[5] Suparmoko.2002.Ekonomi publik untuk keuangan dan pembangunan daerah.Andi.Yogyakarta

[6] Grigalunas T.S dan R. Congar. 1995. Environmental economics for integrated coastal area management: valuation methods and policy instruments. UNEP Regional Seas Reports and Studies. No. 164. UNEP.

[7] Freeman III, A.M. 2003. The measurement of environmental and resource values. Resources for The Future. Washington, D.C.

[8] Orchard, S. E., Stringer, L. C., \& Manyatsi, A. M. 2017. Farmer Perceptions and Responses to Soil Degradation in Swaziland. Land degradation \& development, 28(1), 46-56. doi:10.1002/ldr.2595

[9] Saguye, T S. 2017. Analysis of farmers' perception on the impact of land degradation hazard on agricultural land productivity in Jeldu district in West Shewa Zone, Oromia, Ethiopia. Journal of Agricultural Extension and Rural Development. Vol.9(6), pp. 111-123, June 2017 DOI 10.5897/JAERD2017.0854

[10] Joshi, P. K., Wani, S. P., Chopde, \& Foster, V. K., J. 1996. Farmers' Perception of Land Degradation: A Case Study. Economic and Political Weekly, 31(26), A89-A92. Retrieved from http://www.jstor.org/stable/4404335.

[11] Kassa, Y., Beyene, F., Haji, J., Legesse, B. 2013. Farmers' Perception of the Impact of Land Degradation and Soil and Water Conservation Measures in West Harerghe Zone of Oromia National Regional State, Ethiopia. Journal of Biology, Agriculture and Healthcare ISSN 22243208 (Paper) ISSN 2225-093X (Online) Vol.3, No.11, 2013

[12] García-Llorente M., Martín-Ló B., Montes C. 2011. Exploring the motivations of protesters in contingent valuation: Insights for conservation policies. Environmental Science \& Policy, 14: 76-88.

[13] García-Llorente M., Martín-López B., Nunes P.A.L.D., González J.A., Alcorlo P., Montes C. 2011. Analyzing the social factors that influence willingness to pay for the management of invasive alien species under two different strategies: Eradication and prevention. Environmental Management, 48: 418-435.

[14] Bishop R., Heberlein A. 1979. Measuring values of extramarket goods: Are indirect measures biased? American Journal of Agricultural Economics, 61: 926-930. 
[15] Hanley, N. and Splash, C.L. 1993. Cost of Benefit Analysis and the Environment. Edward Elgar Publishing Ltd., Cheltenham

[16] Janků, J., Kučerová, D., Houška, J., Kozák, J. And Rubešová, A. 2014. The Evaluation of Degraded Land by Application of the Contingent Method. Soil \& Water Res., 9, 2014 (4): 214-223

[17] Hanemann W.M. 1984. Welfare evaluations in contingent valuation experiments with discrete responses. American Journal of Agricultural Economics, 66: 332-341.

[18] Mitchell R.C., Carson R.T. 1989. Using Surveys to Value Public Goods. The Contingent Valuation Method. Resources for the Future, Washington, D.C.

[19] Pratiwi S R, Purnomo E, Usman S, Gravitiani E 2018 Farmers' willingness to pay for the environmental restoration of the critical land at North Kalimantan IOP Conference Series: Earth and Environmental Science 200 (1) 012015

[20] Abdeta, G C., Geleto, G M. 2018. Farmers' Perception on Land Degradation and Adoption of Soil-Water Conservation Measures in Ethiopian Highlands: Review Article. 2018. Journal of Resources Development and Management www.iiste.org. ISSN 2422-8397 An International Peer-reviewed Journal Vol.40, 2018 36-54
[21] Adimassu Z, Kessler A, Yirga C, Stroosnijder L. 2013. Farmers' perceptions of land degradation and their investments in land management: a case study in the Central Rift Valley of Ethiopia. Environ Manage. 2013 May;51(5):989-98. doi: 10.1007/s00267-013-0030-z.

[22] Assefa E, Hans-Rudolf B. 2016. Farmers' perception of land degradation and traditional knowledge in southern Ethiopia -Resilience and stability. Land Degrad. Dev. 27(6):1552-1561.

[23] Zhihui Li, Xiangzheng Deng, Fang Yin, and Cuiyuan Yang. 2015.Analysis of Climate and Land Use Changes Impacts on Land Degradation in the North China Plain. Advances in Meteorology, vol. 2015, Article ID 976370, 11 pages, 2015. https://doi.org/10.1155/2015/976370.

[24] Edward B. Barbier, P. Sanchez, R. Thomas and A. Wagner. The Economic Determinants of Land Degradation in Developing Countries. 1997. Philosophical Transactions: Biological Sciences Vol. 352, No. 1356, Land Resources: On the Edge of the Malthusion Precipice? (Jul. 29, 1997), pp. 891-899

[25] H. Long, G. Tang, X. Li, and G. K. Heilig. 2007. Socio-economic driving forces of land-use change in Kunshan, the Yangtze River Delta economic area of China. Journal of Environmental Management, vol. 83 , no. 3, pp. 351-364, 2007. 